\title{
Catalysing entrepreneurship in and around universities
}

\author{
Gilles Duruflé, Thomas Hellmann, and Karen Wilson
}

May 2018

\section{Contents}

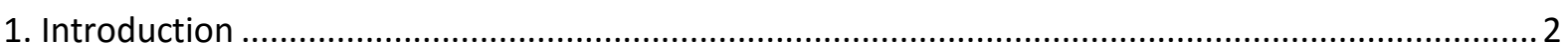

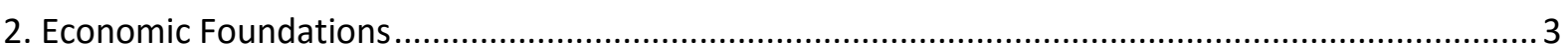

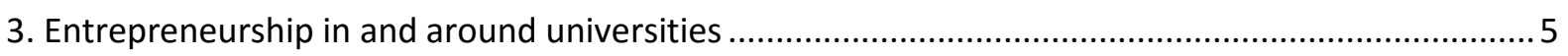

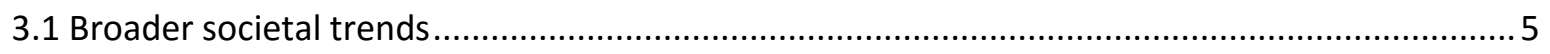

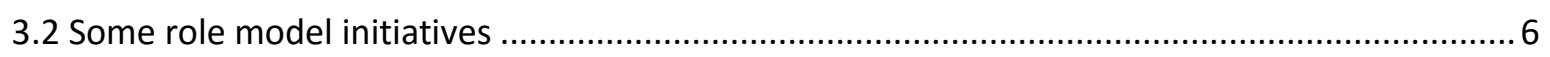

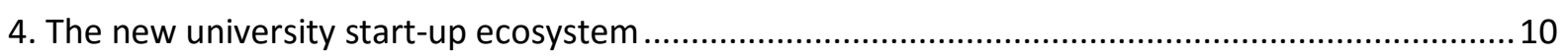

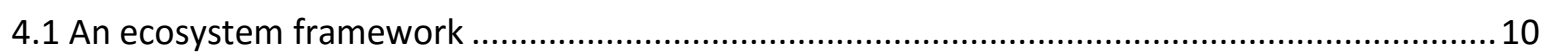

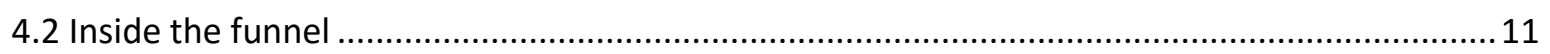

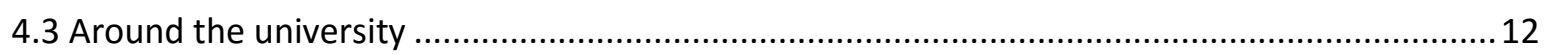

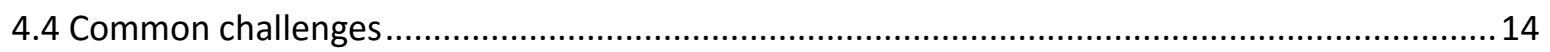

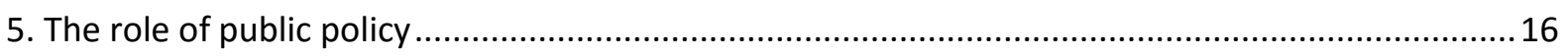

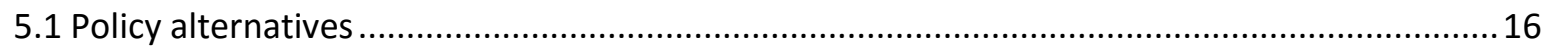

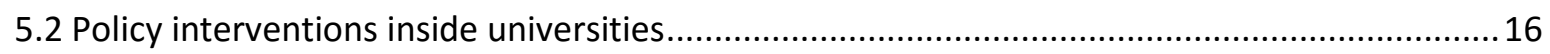

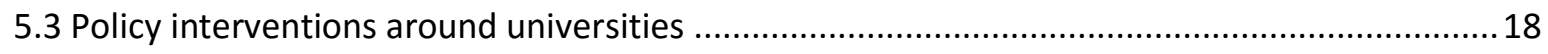

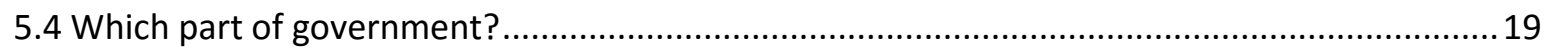

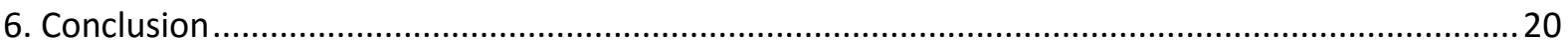

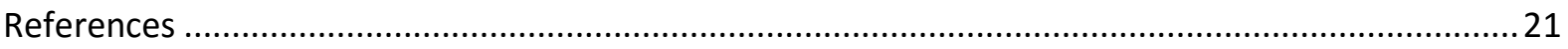

Gilles Durufle is the President of the QCC Tech Innovation Platform (formerly Public Policy Forum on Venture Capital and Innovation) (Email: gdurufle@quebeccityconference.com). Thomas Hellmann is a Professor of Entrepreneurship and Innovation at the Saïd Business School, University of Oxford (thomas.hellmann@sbs.ox.ac.uk). Karen Wilson has been working at the OECD since 2009 and is the founder of GV Partners (Email: karen@gvpartners.com). The authors greatly benefited from the comments of Dieter Helm, Colin Mayer, Mike Wright, an anonymous referee, and the participants of the $3^{\text {rd }}$ Oxford Entrepreneurship Policy Roundtable (May 2017). Special thanks goes to Carolyn Hicks for her valuable research assistance. 


\section{Introduction}

Change is not the first thing that comes to mind when thinking of universities. After all, they are one of the few institutions that survived the medieval ages. Yet over the last few decades there has been a remarkable evolution in the roles and functioning of modern universities (Wildavsky, 2010). In addition to the two traditional core pillars or teaching and research, a third role has emerged that may be broadly characterized as serving as a hub of innovation and entrepreneurship.

The first wave of this change is associated with the creation of university technology transfer offices, where universities are viewed as a 'source' of innovation. In the last two decades of the $20^{\text {th }}$ century, following the introduction of the Bayh-Dole act in the US, research-based universities in the US and later other countries established technology transfer offices (Litan et al, 2007). They adopted a wide range of practices for commercializing research, thus engaging in commercial transactions with private businesses. In addition to licensing intellectual property to established corporations, universities started to create their own academic spin-off companies, thereby entering the entrepreneurship arena. A large prior literature examines this first wave of university-based technology commercialization. Of particular note is the work of Debackere and Veugelers (2005), Shane (2004), Siegel, Waldman and Link (2003), Siegel et al. (2007), and Chapter 1 of Wright et al. (2018).

Since the turn of the century there has been a second wave of entrepreneurial activity in and around universities in which universities increasingly became a 'hub' of innovation not just a 'source'. A growing number of universities are recognizing the substantial economic impact of their student and alumni entrepreneurs, whose companies create jobs and generate significant annual revenues (MIT, 2009; 2014). This wave has brought to campus activities such as accelerators, co-working hubs, and maker spaces. It involves a much broader cross-section of actors both within and outside the university (OECD, 2008). We call the companies coming out of this second wave "university-based start-ups", and distinguish them from the typical "academic spin-offs" of the first wave. Siegel and Wright (2015) discuss the evolution of this second wave. Chapter 2 of Wright et al. (2018) further expands on this.

This paper is an exploratory study that focuses on this second wave. It argues that the second wave is fundamentally different from the first, involving a broader set of actors and challenges. While the first wave of academic spin-offs was largely driven by the commercialization of intellectual property, the second wave of university-based start-ups has been driven by "students". Let us define the term "student" upfront. Our definition involves not only undergraduate students, but also graduate students (both at masters and doctoral level), as well as post-doctoral students. Moreover, while the seeds of the entrepreneurial venture are often planted during their time as students, the development of university-based start-ups usually occurs as alumni, i.e., after graduation (or interruption of studies). Some entrepreneurial activity is also driven by entrepreneurs who never directly enrol in the university, but forge a variety of collaborations with parts of the university. 
The central research question we ask in this paper is what public policies governments can adopt with respect to "university-based entrepreneurship". In order to answer this question, we establish three important foundations. First, we develop an understanding of the potential role of government in terms of supporting entrepreneurship at universities and in the ecosystem around them. For this purpose Section 2 examines the existing literatures on entrepreneurship and the role of government. That section draws on the work of Lerner (2009), Gerbin and Drnovsek (2016), Sandström et al. (2016), and Wilson (2015). Second, we need an understanding of the emerging phenomenon. Unfortunately there is little in terms of systematic data, let alone rigorous empirical analysis. However, in Section 3 we give a more exploratory description, providing examples from different university environments. Third, to bring coherence to our discussion we introduce in Section 4 a simple descriptive framework for comprehending this second wave of university-based start-ups. This framework considers how university-based start-ups interact with a variety of external parties, such as investors and corporations, thereby creating an entrepreneurial ecosystem.

With these three foundations in place, Section 5 addresses the role of public policy for promoting university-based start-ups. Our goal is to identify the potential actions governments can take to promote entrepreneurship in and around universities, and to assess the main advantages and disadvantages of such policy interventions. ${ }^{1}$

\section{Economic Foundations}

A long tradition in economics places the entrepreneur at the centre of economic growth. In the work of Schumpeter $(1934,1942)$, entrepreneurs play a central role in the process of creative destruction. In the Austrian school, especially the work of Kirzner (1973), entrepreneurs help to guide the economy towards new equilibria. In the endogenous growth theories of Romer (1994) innovation is the main driver of long-term growth, although entrepreneurs are not explicitly modelled. Aghion and Howitt $(1992,2009)$ build on the ideas of Schumpeter to build an endogenous growth theory where entrepreneurs and firm entry are central. Parker (2018) provides a useful summary of this literature.

Complementing these theoretical contributions, a recent empirical literature looks at the importance of innovation and entrepreneurship (Cohen (2010), Kerr et al. (2014)). Closely related, there is a burgeoning literature on entrepreneurship and job creation. The work of Haltiwanger et al. (2013), for example, shows that young firms (not small firms!) are an important engine of job growth. See also the paper by Block et al. (2018) in this same issue.

The relationship between entrepreneurship and economic growth on its own does not justify government intervention, there must also be some market failure. A large economics literature identifies three broad types of market failures. First, it has been established numerous times that asymmetries of information generate inefficient market equilibria. The

\footnotetext{
${ }^{1}$ It is also useful to mention what we do not attempt in this paper. First, we do not examine the first wave of academic spin-offs. Second, we do not discuss how to teach entrepreneurship, and the various pedagogical challenges associated with that.
} 
work of Akerlof (1970), Greenwald and Stiglitz (1986), and Holmström (1982), amongst others, shows how various types of information asymmetries lead to an undersupply of worthwhile economic activities. Second, a large innovation literature discusses the 'public good' nature of information (Arrow, 1962). The externalities associated with the generation and dissemination of innovation again lead to an undersupply of economic activities. Finally, there is a long tradition amongst institutional economists not to take markets for granted. They consider the underlying 'institutions' that are required for market transactions (North, 1990). Formal models point to the existence of multiple equilibria, such as the seminal work of Murphy et al. (1989) about the big push. The work of Michelacci and Suarez (2004), Landier (2006), and Hellmann and Thiele (2018), amongst others, use similar models to show how there can be multiple equilibria with respect to the level of entrepreneurial activity.

All three types of market failures suggest a tentative role for government actions to promote entrepreneurial activity. However, the benefits of any government intervention have to be weighed against their potential downsides. Any government action has some costs associated with it, including programme and administrative costs, as well as the distortionary costs of taxation that come from the government's funding needs (Slemrod (1990)). Finally, there are numerous political and bureaucratic reasons why government actions can be misguided or ineffective (Becker (1983), Olson (1965), Peltzman (1976)).

Focusing now more specifically on the roles and responsibilities of universities, let us take a look at the relationship between education and entrepreneurship. Fuelled by prominent examples, such as Steve Jobs and Bill Gates, there is a popular notion that higher education is unnecessary for entrepreneurs, and that 'dropping out of college' is a promising step on the path to entrepreneurial success. Recent empirical studies, however, indicate that the opposite is true: students who complete their degrees perform better in terms of entrepreneurial success and earnings. Moreover, while there is relatively little data on the relationship between types of educational experiences and entrepreneurial outcomes, several studies shed some indirect light on this questions. In a study of Stanford graduates, Lazear (2005) finds that students with broader backgrounds and learning experiences are more likely to become entrepreneurs. Second, in a study of Harvard students, Lerner and Malmendier (2013) find that student entrepreneurs benefit from the feedback of their peers. The work by Autio (2010) also reinforces the influence of peers in the pursuit of entrepreneurial careers.

In this paper we examine the role of government policy for university-based start-ups. In 2006, the European Commission issued a communication on 'Fostering entrepreneurial mind sets through education and learning' which highlighted the importance of entrepreneurship in education at all levels, including in higher education. This led to a series of projects and policy guidance, including the 'Oslo Agenda for Entrepreneurship Education in Europe which made a set of policy recommendations which include university activities 
beyond teaching as well as links with external stakeholders. ${ }^{2}$ Policy interest in the role of universities in the entrepreneurial ecosystem has increased in many countries over the past decade.

In conclusion, there is a solid body of prior economic research that identifies a role for entrepreneurs for innovation and economic growth. Several important market failures justify in principle a role for government intervention, although the benefits of any intervention have to be compared against their costs. Universities appear to play an important role in the process of how individuals become entrepreneurs. As a consequence there is a potential role for governments to foster entrepreneurial activities in and around universities. In Section 5 we will lay out the policy alternatives that governments face. Before doing so, however, we first need a better understanding of the phenomenon of university-based start-ups. We develop this over the next two sections.

\section{Entrepreneurship in and around universities \\ 3.1 Broader societal trends}

Ideally there would be plenty of data to study the emergence and nature of the growing entrepreneurial ecosystem in and around universities. . Unfortunately, however, systematic data is sparse. In this study we therefore aim to provide a more qualitative and exploratory description of the emerging phenomenon.

In order to appreciate the unique aspects of the wave of university-based start-ups, it is useful to briefly discuss the initial wave of academic spin-offs. Those companies emerged mostly from limited areas of academic studies, mostly in engineering, computer sciences, the physical sciences, and the life sciences, where intellectual property is common. The new types of university-based start-ups, however, touch upon a much broader range of academic disciplines that also reach into the social sciences, the humanities, even the arts. There is also a significant interest from business school students, who learn their entrepreneurial tool box in class, and then seek business ideas and partners from across the university to launch new ventures. The types of ventures launched therefore are highly varied: from mobile phone apps, to deep tech, digital health solutions, specialized consulting, educational initiatives, all the way to social ventures.

This second wave of university-based start-ups did not emerge in a vacuum, but finds its origins in a number of broader trends that arose outside the university. The Internet has dramatically increased access to information, including how to start a business. Closely related is the rise of the lean start-up movement, which helps entrepreneurs to develop their business model iteratively and cheaply. ${ }^{3}$ This approach to starting businesses is often practiced in so-called accelerators. These accelerators are a further evolution of the old model of business incubators where start-up companies could find office space for an indefinite time period. Instead accelerators are targeted towards specific needs of

\footnotetext{
${ }^{2}$ See https://ec.europa.eu/growth/smes/promoting-entrepreneurship/support/education/commissionactions en and https://ec.europa.eu/growth/smes/promotingentrepreneurship/support/education/commission-actions en

${ }^{3}$ See Blank (2013) and Reis (2011).
} 
entrepreneurial teams, and emphasize intensive training programs with rich peer interactions, often focused on a clear goal of pitching at a demo day. ${ }^{4}$ In addition, crowdfunding and growth in other financing sources, such as angel investors (Wilson, 2011) has increased the access to funding for early-stage projects and ventures. ${ }^{5}$ Also of note is the emergence of open innovation systems which emphasizes collaboration and deemphasizes formal intellectual property. ${ }^{6}$ All of these trends have lead the development of entrepreneurial ecosystems in which universities serve an important hub (EFER, 2007), creating new windows of opportunities for students to launch their own ventures.

The rise of university-based start-ups also needs to be understood in the light of changing student job markets. Especially in the aftermath of the most recent financial crisis, students face lower prospects of finding stable employment with large established corporations. Competition has also increased for a limited number of academic positions. Thus it is not surprising that students and young professionals increasingly take interest in entrepreneurship as an alternative career option.

\subsection{Some role model initiatives}

We now consider a variety of university-based initiatives that are considered role models. ${ }^{7}$ Again we emphasize the exploratory nature of this, and note that there is a need for future research to gather more systematic evidence.

MIT stands out as a leading role model. A report by Roberts, Murray and Kim (2015) describes the overall innovation and entrepreneurship activities at MIT. A notable feature is that entrepreneurship is not only pervasive across the entire university, it is also highly decentralized. Different parts of the university pursue different programs, generating considerable diversity, and occasional overlap. The majority of entrepreneurial activities focus around technology-based ideas. Some initiatives broaden this focus, such as the Deshpande centre which focuses on bringing technology-based solutions to social problems in developing countries. ${ }^{8}$ In order to bring some coherence to this plethora of decentralized activities, the university launched the MIT Innovation Initiative, which serves as a connector, and tries to fill any remaining gaps in landscape. ${ }^{9}$

Stanford University is another important role model. Again we find that initiatives are decentralized. Some important ones come out of the Stanford Technology Ventures Program, which is hosted in the Engineering school, but many others have different homes. An interesting example is StartX, an accelerator program that is structured entirely outside of the university, yet focuses exclusively on accelerating ventures based from Stanford University. Another fascinating initiative is University Innovation Fellows, based in the

\footnotetext{
${ }^{4}$ See Cohen and Hochberg (2014).

${ }^{5}$ See Agrawal, Catalini and Goldfarb (2014).

${ }^{6}$ See Chesborough (2003) and Lerner (2012).

${ }^{7}$ See also Graham (2014) for a useful report on this.

${ }^{8}$ See http://deshpande.mit.edu/

9 See MIT (2016) and https://innovation.mit.edu/
} 
Stanford D.school. ${ }^{10}$ This is less of a program for Stanford students, instead it is a global 'meta-program'. It encourages students from around the world to become catalysts in their respective universities, specifically training students how to set up bottom-up entrepreneurship initiatives in their home institutions. ${ }^{11}$

In Canada, Communitech in Waterloo/Kitchener is an interesting example of a "community tech hub".$^{12}$ It was started at the initiative of leaders of local large tech companies (RIM, Opentext and Christie Digital) and is built in and around two universities: the University of Waterloo, and Wilfrid Laurier University. It includes incubators/accelerators on and off campus, and a large co-working space that hosts both start-ups and innovation teams from large corporations. The key components of Communitech are (i) its community of entrepreneurs that benefits from a large array of services provided by the Communitech team; (ii) its corporate anchor tenants; (iii) its two anchor universities, and (iv) government funding. One interesting aspect that has attracted a large number of entrepreneurially minded students, as well as recruiting firms, multinational companies and local start-ups, is its co-op program, which provides flexible ways of combining academic studies and corporate internships. ${ }^{13}$

Toronto's Ryerson University provides another intriguing example of an innovative approach to promoting entrepreneurship. The Ryerson DMZ (which stands for Digital Media Zone) initiative was led from the top of the university administration, who created a large physical entrepreneurship space in the middle of town. ${ }^{14}$ It provides co-working spaces and programmes not only for its own students, but also the metropolitan community of entrepreneurs, investors, and corporations. According to Duruflé (2016), DMZ is changing the dynamics of the academic ecosystem and establishing a mind-set of entrepreneurship and experiential learning across the university. Of particular note is its approach to forging strategic relationships with large established corporations. Rogers, one of Canada's leading telecommunication providers, for example, engaged with Ryerson Futures, the University's accelerator program, to identify new products and services, accelerate its own development times, and build its employees' skills set and cultures. ${ }^{15}$

Near to Ryerson is the University of Toronto, recognized as a world-class research university. It also hosts a variety of programs, although their origins and approaches are very different. Its most significant initiative, the Creative Destruction Lab $(C D L)$, requires no physical space at all. ${ }^{16}$ This initiative was started by Dr. Ajay Agrawal, an entrepreneurial-minded academic, who envisioned a university-based acceleration program that would focus on challengebased learning, where experienced entrepreneurs set challenges to young university-based

\footnotetext{
${ }^{10}$ The D.school's full name is the Hasso Plattner Institute of Design: https://dschool.stanford.edu/. Details on the University Innovation Fellows program can be found at: https://dschool.stanford.edu/universityinnovation/university-innovation-fellows.

${ }^{11}$ See Britos Cavagnaro and Fasihuddin (2016)

12 See https://www.communitech.ca/

${ }^{13}$ See Duruflé (2016)

${ }^{14}$ See https://dmz.ryerson.ca/

${ }^{15}$ See Duruflé (2017)

${ }^{16}$ See https://www.creativedestructionlab.com/
} 
venture teams. Initially his efforts were not supported by the university, so he launched the programme outside of the university's formal structure. Once the program became successful, the Rotman School of Management was eager to integrate it, and make it a central pillar of its marketing campaigns. The original circumstances left a mark on the program. For example, the program was never limited to students of the University of Toronto, and therefore continues to attract ventures not only from Toronto, but also the rest of Canada and beyond. The model was so successful that it was franchised out to other North American universities, first to Vancouver (University of British Columbia), and subsequently to Calgary, Halifax, Montreal, and most recently New York University. ${ }^{17}$

In Europe, Aalto University, located in Helsinki, Finland, is one of the role models for entrepreneurship. The university was formed in $\mathbf{2 0 1 0}$ out of a three-way merger of the Helsinki University of Technology, the Helsinki School of Economics, and the University of Art and Design Helsinki. ${ }^{18}$ In the face of initial scepticism about the wisdom of combining such heterogeneous entities, Aalto found that entrepreneurship provided a common ground between these diverse groups. Of particular interest is the inclusion of arts and design. This coincided with the broader recognition of design thinking as being relevant to entrepreneurial ventures, a movement inspired by the influential writings of Tim Brown, CEO of IDEO. ${ }^{19}$ Today Aalto University hosts the Aalto Design Factory, Aalto Ventures Program, and Aalto Entrepreneurship Society (Aaltoes). ${ }^{20}$ Moreover, around the university there are entrepreneurship initiatives such as the start-up sauna accelerator programme, as well as SLUSH, the largest entrepreneurship conference in Europe. ${ }^{21}$

Technical universities have increasingly become hubs of entrepreneurship. One example is the Technical University of Munich (TUM). Over a decade ago, the President of the University made a commitment to turning TUM into an "entrepreneurial university". In addition to creating entrepreneurship chairs and embedding entrepreneurship more deeply into the curriculum across the university, a set of activities targeting students, alumni, entrepreneurs and other stakeholders were developed. Today TUM is one of the leading entrepreneurial hubs in Germany. ${ }^{22}$ Other examples include Innogrants at the EPFL in Switzerland, and Skylab at the Technical University of Denmark. ${ }^{23}$ In 2008, the EU also set up the European Institute of Technology and Innovation (EIT) to boost entrepreneurship and innovation in Europe by bringing together leading higher education institutions, research labs, and companies, to form dynamic cross-border partnerships. ${ }^{24}$

The challenges of bringing entrepreneurship to traditional research-based universities can be seen at the University of Oxford. Steeped in tradition, and organized in a highly decentralized fashion around departments and colleges, the concept of entrepreneurship

\footnotetext{
${ }^{17}$ See https://www.creativedestructionlab.com/locations/

${ }^{18}$ See https://en.wikipedia.org/wiki/Aalto University

${ }^{19}$ See Brown (2009)

${ }^{20}$ See https://designfactory.aalto.fi/, http://avp.aalto.fi/, and https://aaltoes.com/

${ }^{21}$ See http://startupsauna.com/accelerator/and http://www.slush.org/

${ }^{22}$ See https://www.tum.de/en/tum-business/entrepreneurship/

${ }^{23}$ See https://vpi.epfl.ch/innogrant and http://www.skylab.dtu.dk/.

${ }^{24}$ See https://eit.europa.eu/
} 
does not fit easily into the existing structure. Yet the same societal forces promoting entrepreneurial thinking and action also affect its student body, its research faculty, and its surrounding environment. Before the turn of the century the university created a technology transfer office and a business school. Since then many entrepreneurship programs have been launched. While arguably lagging other universities, Oxford is developing a strong and highly creative entrepreneurship scene.

During the first wave of academic spin-offs, Oxford's technology transfer office (recently renamed Oxford University Innovation) became an internationally sought-after centre of expertise. ${ }^{25}$ Leveraging this strength, Oxford Science Innovation raised around $£ 580 \mathrm{M}$ (approx. \$770M), to be invested in Oxford spin-off companies. ${ }^{26}$ This is a private venture capital firm (run by an Oxford alumni) that struck a unique deal with the university, where the university owns a permanent stake in the venture capital firm, in exchange for partial ownership of the university's intellectual property portfolio.

There is also considerable student interest in 'second wave' entrepreneurship activities. Oxford Entrepreneurs, a student society focused on entrepreneurship claims to be "Europe's largest student Entrepreneurship Society". ${ }^{27}$ In 2017, under the leadership of the Saïd Business School, the Oxford Foundry was opened. ${ }^{28}$ This is a student-facing entrepreneurship centre for the entire Oxford student population, nurturing a community of like-minded entrepreneurial students. Even though a late comer, Oxford's entrepreneurial ecosystem developed quickly, and is rapidly catching up with its international peers. If a traditional university like Oxford can make such a transformation, it might be a sign that university-based start-ups are more than just a fleeting fad.

In this section we have provided numerous examples from various geographies that illustrate the emergence of university-centric entrepreneurship ecosystems. To provide a balanced picture, we should point out that not all entrepreneurial ecosystems are centred on universities. Many successful entrepreneurial initiatives happen without any university involvement at all. Accelerator programs such as the Y-Combinator or TechStars may involve many young entrepreneurs, including recently graduated students, but they do not rely on a university environment. The same can be said about corporate accelerators and intrapreneurial training programs. Moreover, some ecosystems operate without significant inputs from universities. London's FinTech scene is a good example of that. This also related to questions about the geographic distribution of entrepreneurial activity, discussed in this same special issue by Audretsch (2018).

Finally note that some entrepreneurial initiatives are openly hostile to traditional universities. Draper University (also known as "Draper University for Heroes") is a for-profit school for entrepreneurs in Silicon Valley that deliberately distances itself from the traditional research university model. ${ }^{29}$ Another example is the Thiel Fellowship, which

\footnotetext{
${ }^{25}$ See https://innovation.ox.ac.uk/

${ }^{26}$ See https://www.oxfordsciencesinnovation.com/

27 See http://oxfordentrepreneurs.co.uk/

${ }^{28}$ See https://www.oxfordfoundry.ox.ac.uk/

${ }^{29}$ See https://www.draperuniversity.com/
} 
famously pays students to drop out of college to start their business. ${ }^{30}$ We would contend that these examples are the exceptions that prove the norm. While there is no systematic data to prove it, our observations suggest that an increasing number of universities are embracing numerous types of entrepreneurship initiatives, and that local ecosystems embrace their efforts. Together they form this second wave of student-led entrepreneurial activity.

\section{The new university start-up ecosystem}

\subsection{An ecosystem framework}

In order to make sense of recent entrepreneurship developments in and around universities, we now develop a simple descriptive framework. While every university clearly has its own distinct ecosystem, the framework tries to capture the essence of what a welldeveloped system might look like, based on the examples that have been studied to date.

Figure 1 provides a graphical representation of our core framework that we call the university entrepreneurship funnel. In reality, the ecosystem is naturally more complex and less linear, but the framework provides a useful structure for thinking about the core actors and processes within the ecosystem.

\section{Figure 1: The ecosystem in and around universities}

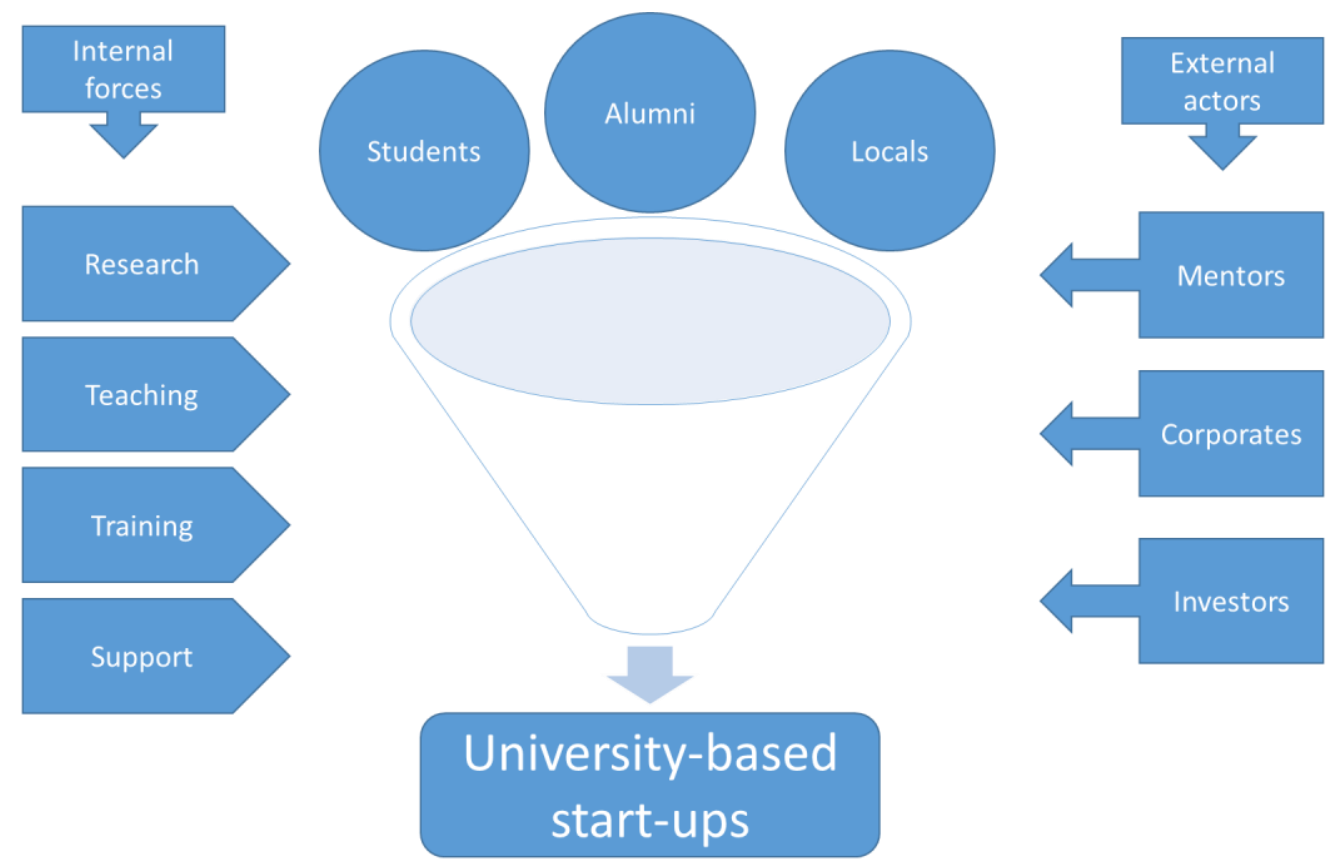

The framework focuses on the creation of university-based start-ups, which are shown at the bottom as the output of ecosystem interactions. The central agents are nascent entrepreneurs, which include not only students, but also alumni and other locals that collaborate with people in the university. In some cases faculty members also collaborate with students and even take entrepreneurial initiatives by themselves. They are going through a process that is represented by the funnel, which we will describe in further detail

\footnotetext{
${ }^{30}$ See http://thielfellowship.org/
} 
below. Throughout this process these nascent university-based entrepreneurs benefit from a rich set of interactions with others, both within and around the university.

The main forces within the university are represented on the left-hand side. At the early stages there can be interactions with the two traditional functions of universities, namely research and teaching. On the research side, the nascent entrepreneur can draw on the insights of the research undertaken at the university, focusing on how research ideas and inventions can be used for commercial or social purposes. While this may sometimes involve intellectual property (taking us back to the older academic spin-off model), oftentimes it doesn't. In addition there are ideas coming out of the teaching side of university activities. As a starting point for their own entrepreneurial ideas, students may get inspired by new ideas about societal problems (e.g., water scarcity), new technologies (e.g., artificial intelligence), or new business models (e.g., the sharing economy). The difference between teaching and training is mainly that teaching concerns traditional academic curriculum courses that expose students to a large and diverse body of knowledge. Training is more practical and mostly focuses on developing skills. Much of this happens in an extracurriculum setting, although some skills training has also found its way into the curriculum. Finally, universities increasingly have programs to support the entrepreneurial journey (see section 3).

The main interactions around the university are represented on the right hand side, which shows the external actors. In the early stages, nascent entrepreneurs often benefit from mentors and role models who inspire them to explore their ideas, and guide them through the initial steps of the entrepreneurial process. Oftentimes these mentors are either part of the local entrepreneurial community, or accomplished alumni of the university. In some case mentors are also inside the university, most notably faculty and staff. As projects progress, there can be interactions with corporations. For investments, there are typically some local angel investors - mentors can turn to be angel investors -, and sometimes even venture capital firms. They participate in the ecosystem with a view to sourcing investment deals.

\subsection{Inside the funnel}

Let us now take a deeper look at the transformation that occurs within the funnel. At the top of the funnel we are dealing with students (broadly defined, including recent alumni), curious minds who get intrigued by some opportunity or challenge. At the bottom of the channel we find committed entrepreneurs who launch their own start-up companies.

It is useful to broadly distinguish three stages along the funnel. As shown in Figure 2 below, we label then "Inspire", "Engage", and "Accelerate". They describe the natural progression from a curious mind, to an experiential learner, to a dedicated entrepreneur. At the top of the funnel students broaden their interests, follow up on their curiosity, and open their entrepreneurial mind set. As they progress through the funnel they start to engage with the process, they experiment, they learn experientially, and they develop an entrepreneurial skill set. At the bottom of the funnel they make career choices about whether or not to become an entrepreneur, founding a proper entrepreneurial venture. 
Figure 2: Inside the funnel

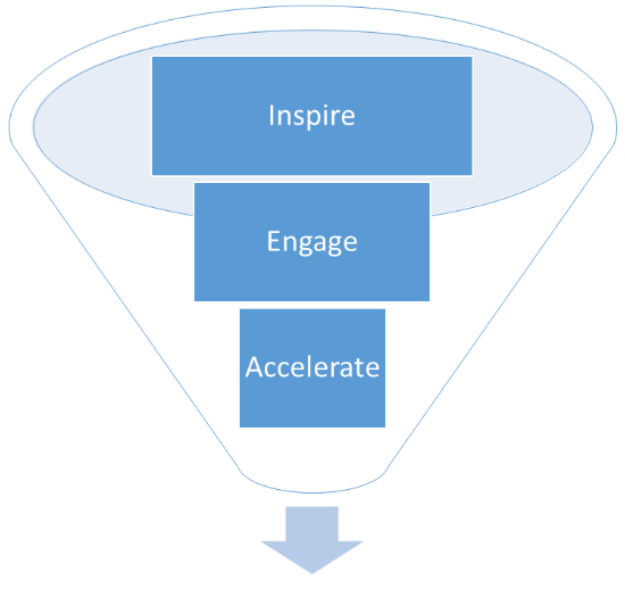

To give some examples, typical activities at the top of the funnel include listening to inspiring speakers, or participating in a hackathon. In the middle of the funnel they might attend some skills workshops, or participate in a business plan competition. At the bottom of the funnel they might participate in an accelerator programme, work out of an incubator space, or pitch their business to potential investors.

Not only do the goals of the students change along the funnel, so do the objectives of the university. At the top of the funnel, the university hopes to provide an environment that is intellectually stimulating and inspiring to its students. In the middle of the funnel, entrepreneurship training plays into a larger university agenda of skills development. This has become more important in recent years as universities are increasingly held accountable not only to teach abstract concepts, but also to prepare students for professional life, including entrepreneurial attributes, skills, and behaviours. At the bottom of the funnel, universities want to demonstrate their impact on students, business, and society at large, highlighting their entrepreneurial success stories.

Along the way there is a lot of natural attrition. Students might decide that entrepreneurship is not for them. They veer off to adjacent activities, such as pursuing an intrapreneurial career in existing organizations, becoming innovators within organizations, or pursuing other creative activities. Even if only a relatively small number of students go all the way through the funnel, many learn some entrepreneurial skills along the way that they can usefully deploy elsewhere. This is important from the university's perspective, which has a broader objective than just maximizing the number of university-based start-ups.

\subsection{Around the university}

Universities are increasingly embedded in their local entrepreneurial ecosystems, interacting with a large variety of other institutions and private individuals, such as mentors, investors, corporations, and government. Each of these four constituents have different roles and objectives, and face different challenges in the process. We use the term mentors broadly to describe private individuals that interact with university-based start-ups. They 
have a range of objectives. At one end there is a purely benevolent desire to help the next generation of students, and give back to the university. On the other end there is much more self-interest. Some mentors have an eye on joining a promising start-up (often as CEO or board members), others seek to make a financial investment, or other business transactions. The main challenges faced by these mentors are finding a match that fits their expertise and interests, as well as finding the time and space to have meaningful interactions.

There is a thin line between mentors and investors, because investors frequently interact with teams as mentors before committing any funding. Most of the investors around universities are angel investors, often alumni of the university. In recent years, seed funds and even venture capital funds have been raised with a mandate to invest in and around universities. The objectives of angels and venture capitalists is to generate a return on investment. Doubtlessly many also want to help young entrepreneurs, and foster the local ecosystem. Their main challenges are identifying the most promising ventures, and helping them develop their business. In the case of academic spin-offs, there is the added complexity of structuring a deal with the university about the intellectual property.

Corporations are increasingly taking interest in university start-up ecosystems, although they approach it from a different angle. Certain service providers, such as lawyers, accountants, and consultants simply look for new clients. Other corporations have a more strategic perspective. They want to learn about new opportunities that might become relevant for their own businesses. They also want to interact with students and alumni, with an eye towards recruiting. Corporations can strike some formal or informal partnerships with relevant university entities. They often sponsor events, provide mentors and experts to nascent entrepreneurs, or set up innovation teams within university innovation hubs. Their main challenge is extracting value out of a partnership, whilst at the same time navigating sensitivities around academic freedom.

Finally, we consider governments as an additional 'player' in the ecosystem. We will discuss this in greater detail in our policy analysis of Section 5. In Section 5.4 we further recognize that different parts of government look after different parts of the ecosystem.

It is worth noting that some of the dynamics within these ecosystems. Younger generations of entrepreneurs are mentored and funded by an older generation of entrepreneurs, often from the same ecosystem. ${ }^{31}$ Similarly, corporations may be run by executives who are alumni from the university and want to give back to the place that helped them launch their careers. Alumni loyalty is an important factors, many students appreciate their time at university, and some benefit from financial support, including bursaries and fellowships. Decades later they 'pay back' by making philanthropic donations to set up entrepreneurship centres, endow entrepreneurship professorships, or support other entrepreneurship activities. Similar dynamics apply to corporations. Start-ups that benefit from the support of

\footnotetext{
${ }^{31}$ See Hellmann and Thiele (2017).
} 
their university may decide years later, to give back to their universities through corporate research funding or scholarship programs.

\subsection{Common challenges}

While the analysis so far may paint a picture of harmonious cooperation within ecosystems, in reality there are many points of frictions. In this section we examine where some of these fault lines lie.

To begin with, it should be noted that most universities are fairly decentralized organizations where the central administration has limited powers. Decision power is frequently devolved to individual departments, programs, even individuals. Moreover, decision makers are influenced by multiple stakeholders, including faculty, student organizations, research councils, government, etc. Although there are exceptions, many universities find it difficult to develop a coherent entrepreneurship strategy. Instead, we can think of the university, as well as its surrounding actors, as an interactive ecosystem where some people take initiatives, others oppose them.

Consistent with this decentralized notion of the university, many entrepreneurship initiatives are launched by individuals further down university hierarchy, often without the explicit blessing of their higher-ups. Once successful, the faculty and administration are more likely to give their blessing. An example in point is the Creative Destruction Lab, discussed in section 3.2 .

The details of how well entrepreneurship initiatives are received clearly depends on the specifics of a university. Certain conflicts appear to be common. We distinguish between conflicts internal to the university, and conflicts between the university and its surrounding entrepreneurial ecosystem. At the risk of oversimplifying, the conflicts between the university and external parties are largely economic in nature, whereas the internal conflicts also involve pedagogical and sometimes ideological differences of opinion.

Most of the challenges in the relationships between universities and external parties concern the contractual arrangements of sharing benefits and costs. While there is often goodwill, and maybe philanthropy, the transactions between a university administration and external parties remains commercial in nature. Standard issues concern the terms of payment, the access and ownership of project outputs (intellectual property or other), and the governance control over the initiatives. A common frustration with university administration is their heavy bureaucracy and slow response time. When it comes to interactions between the university-based start-ups and external parties, there is also a mixture of goodwill and commercial interests. The issues are similar, except that the startups themselves are clearly much less bureaucratic.

Within the university the conflicts can be far more colourful. By and large there are three main constituents, students, faculty, and administration. Each of these is further fragmented into numerous subgroups, each with their own voices and opinions. The possible permutations of who might disagree with whom are almost limitless. Instead of discussing who clashes with whom, let us focus on the substantive issues of conflict. 
First, the concept of "entrepreneurship" (as well as "enterprise" and "business") generates a mixed response within a university. Some welcome it, others harbour negative feelings towards profit seeking. This is sometimes an ideological divide. Other times it is due to a superficial understanding of business and entrepreneurship. Either way, university initiatives often make a point of being highly inclusive, making themselves relevant to a broad class of students, emphasizing entrepreneurial skills, and stressing that entrepreneurs do not only create commercial start-ups, but also social ventures and civic initiatives.

Second, there are fundamental differences of beliefs about what a university should teach. Most people agree that universities should impart students with knowledge and research skills. The question is whether practical skills and vocational training also belong to a university's teaching mission. In some universities a more practical approach is widely accepted, making it easy to integrate entrepreneurial training into the curriculum. In others there is greater emphasis on research and academic teaching, in which case entrepreneurship training occurs mainly outside of the curriculum. ${ }^{32}$

A third set of conflicts revolve around the control of initiatives. Much of this involves standard organizational conflicts about who controls the resources and who gets the credit. An interesting challenge concerns the devolution of control to students themselves. In principle, students have the most to gain, and are oftentimes highly motivated to launch an initiative. However, many student societies are notorious for being fickle and typically lack continuity across years, as leadership teams typically turn over on an annual basis. ${ }^{33}$

Finally it should be noted that universities sometimes have an interesting resource allocation problem: should they devote their resources to helping their most promising projects, or should they distribute their resources more broadly, to give everyone a little bit of support. On the one hand, there is a notion that having a few big winners raises the profile of ecosystem and therefore helps to attract more resources in the future; on the other hand there is a long and cherished tradition of fairness in education, which suggests giving everyone equal access and attention.

It is interesting to note that even though these conflicts were already present in the first wave of academic spin-offs, they are more prominent with the second wave of universitybased start-ups. This is because the first wave was largely centred on faculty and the university's research mission, involving only a limited number of (mostly technologyintensive) departments. The second wave, however, is much closer to the students, and the university's teaching mission. It also involves a much broader cross-section of departments, and therefore reaches a much wider array of different pedagogical and ideological beliefs.

\footnotetext{
32 Moreover, the pressure on faculty to publish their research often takes precedence over all aspects of teaching and training.

${ }^{33}$ Some inspirational counter-examples include SLUSH, which is entirely student-led, as well as some of the initiatives guided by the University Innovation Fellows program, both of which we discussed in Section 3.2.
} 


\section{The role of public policy \\ 5.1 Policy alternatives}

We finally turn to the question of government policies. Our primary goal in this paper is to identify the main types of interventions government can use to promote university-based start-ups. In principle there are numerous policies that governments can devise to support student-led entrepreneurship. The details of such policies are likely to be context specific. We therefore focus on broader categories of potential policy interventions. For this we refer to the frameworks of Section 4. Figure 1 provides a useful overview of the entire ecosystem, and therefore lends itself as a starting point for categorizing government policies. Broadly speaking, we distinguish two classes of policy interventions. First those that are directly aimed at students and universities, and therefore affect the internal forces shown on the left hand size of Figure 1. Second, those that are aimed at the external parties shown on the right hand size of Figure 1. The next two subsections discuss these two classes of interventions.

\subsection{Policy interventions inside universities}

There are numerous actions governments can take to influence the entrepreneurial process inside universities. In many countries universities are heavily funded by government agencies. Thus governments have considerable leverage over most universities. At the same time universities are widely recognized as organizations that benefit the general public, and therefore require protection from undue political influence. Consequently, government policies over universities are often indirect. Rather than prescribing specific actions, governments may start a dialogue, provide incentives, or endorse initiatives. In this way governments have a significant influence over the research, teaching, training, and support activities identified in Figure 1.

On the research side the policy levers date back to the first wave of academic spin-offs, but require some updating. Consider the question of who owns the intellectual property generated at a university. We would argue that there is a clear case of unequivocally giving students the right to own their IP, if and when it comes purely out of their class work. Yet many universities have confusing and sometimes even contradictory rules about studentgenerated IP. Some universities explicitly make a difference between IP that is generated by students and emanates from the teaching side, versus IP that comes out of the research side (with or without student research help), but many don't. This appears to be a case where governments could coax universities to explicitly recognize this distinction, and more broadly clarify their often confusing IP rules.

Having said this, we continue to believe that different rules are required for those students hired as research assistants, as they clearly enter some employment relationship with the university. In practice this means that virtually all undergraduate and most master-level students should be entitled to automatically receive their IP. Doctoral and post-doctoral students, however, would be more likely to fall under the research-side of IP regulation. What the rules on the research should be naturally remains a highly contested question. Recent empirical evidence suggests that the current rules for allocating IP ownership to the 
university are counterproductive, as they create incentives to avoid disclosure, and discourage entrepreneurship (see Hvide and Jones (2016) and Czarnitzki et al. (2017)).

A related question is to what extent universities should help students obtain IP, such as advising them on how to file patents. Once the IP belongs to students, there is no formal obligation to provide such help. However, this might be a natural area where universities can take a proactive step in directly helping the formation of student-led ventures.

On the teaching and training side one policy question concerns the role of entrepreneurial skills training. In recent years there has been an increased emphasis on skills training that complements traditional academic teaching. However, such efforts are rarely systematic, and often focus on basic communication skills (writing, presenting, etc.), rather than more advanced entrepreneurial skills (problem-based thinking, creativity, etc.). One significant program that focuses explicitly on entrepreneurial skills is the I-Corps programme, set up by the National Science Foundation, in cooperation with Steve Blank. ${ }^{34}$ This policy agenda naturally feeds into a wider debate about the merits of academic teaching versus vocational training, and the delicate balance between those two pedagogical approaches (see also O'Connor, 2013).

Support for student entrepreneurs can take many forms, and governments are frequently asked to support some aspects of it. One interesting issue concerns work spaces. As nascent entrepreneurs become more committed, they often look for office space. Co-working spaces have become increasingly popular as a place to both work and socialise, often within a community of similarly-minded people. As start-ups develop further, such co-working spaces no longer suffice. They start to look for more professional office spaces, such as incubators and business parks. Such work spaces for entrepreneurs are increasingly found within or around universities. Some are limited to university members (such as the MIT Entrepreneurship Centre, or the NYU Entrepreneurial Institute), others are open to the broader community (such as Ryerson's DMZ). Governments often get involved in these. At the minimum they have to give planning permissions. Beyond that they can make available underused real estate, and they can initiate local redevelopment plans to attract broader clusters of entrepreneurial activities.

More broadly, governments are often asked to fund various entrepreneurship support initiatives. Based on the arguments of Section 2, there is a potential rationale for government support. However, Section 2 also cautions that some level-headed cost-benefit analysis is desirable. More generally we would argue that in practice most governments can only afford to fund a limited number of initiatives. One useful mechanism to consider in this context is competitive calls for proposals. The government makes available some funding and defines broad application areas, but leaves it to universities (or other related parties) to make competitive proposals. The funding can then be awarded on a merit basis. The Canadian Accelerator an Incubator Program, run by Canada's federal government, is an example in point. ${ }^{35}$

\footnotetext{
${ }^{34}$ See https://steveblank.com/2014/11/20/impact-nyu-scales-the-lean-launchpad.

${ }^{35}$ See https://www.nrc-cnrc.gc.ca/eng/irap/caip/index.html.
} 


\subsection{Policy interventions around universities}

We now turn to the right hand side of Figure 1, which looks at the external forces that affect the ecosystem. Consequently there is a potential role of government for encouraging external actors to better interact with the university as well as student entrepreneurs. The two most important external parties are investors and corporations.

Private investors clearly play a large role in the development of university-based ecosystems. Some governments across the world provide a variety of tax incentives and funding programs that are meant to stimulate investments in entrepreneurial companies. Such programs are typically targeted at angels and venture capitalists. ${ }^{36}$ There is a large prior literature that discusses the strengths and weaknesses of these government programs, the details of which are outside of the scope of this paper.

The key question here is whether governments can do something specific about the financing of university-based start-ups. In principle we would argue that this is hard to justify. Targeting tax credits solely towards universities might create distortions and generate unwarranted favouritism. However, there can still be a role for government policy to ensure that university-based start-ups are not implicitly disadvantaged. For one, university-based start-ups tend to be early stage and therefore high-risk high-return ventures that require experienced risk-tolerant investors. Investment tax credit programs tend to attract a lot of relatively smaller angel investors with limited portfolios and greater risk aversion. Those are not necessarily the type of investors that are willing to take risky bets on science-based technologies, let alone young untested university-based teams. Some venture capital firms also tend to shy away from university-based start-ups, arguing they are too early-stage for their required investment profile. Consequently there is a need for more specialized investment vehicles that have the expertise and risk-appetite to invest in earlystage ventures. The design of government programs should be sensitive to this. A tax credit program for example, should allow for the aggregation of individual angel contributions into angel funds. Government programs that invest capital in venture capital firms should ensure to have a broad mandate that includes university-based seed funds. Government programmes may also consider allowing investment vehicles that have a longer life-span than the standard 10 year terms common in a venture capital partnership. For example, Oxford Science Innovation, the venture capital firm discussed in Section 3.2., is not a 10-year fund, but a limited liability company that has an open investment horizon.

Corporations also play an important role in fostering university-based ecosystems. However, it is not immediately clear that there is a role for government. Tax instruments are likely to be far too broad to be effective in fostering specific collaborations. The role of government appears to be mostly in the realm of persuasion. For example, governments can sometimes play a role in attracting foreign corporations to take a look at local ecosystems. There may also be a role for governments to establish clearer codes of conduct of how corporations can engage with universities in ways that are mutually beneficial, and do not impinge on academic freedom. This is particularly important for publicly owned universities who are

${ }^{36}$ See Wilson $(2011,2015)$ and Wilson and Silva (2013). 
sometimes caught between declining public funding and demanding corporate sponsors. In addition, government agencies can play a helpful role in non-monetary ways, such as raising awareness of success stories, organising trade missions to other jurisdictions, or providing network connections between local and international players.

Finally, there are sometimes teams of ecosystem stakeholders (entrepreneurs, universities, corporations, and investors) that build interfaces between them. These teams can be thought of as "ecosystem builders". They play an important informal role in the joining up the actors described in Figure 1. They are usually financed by a mix of philanthropy, fees for services, and government support. Communitech in Waterloo/Kitchener, discussed in Section 3.2., is an example for that.

\subsection{Which part of government?}

What part of government is responsible for what? The challenge of creating entrepreneurial ecosystems does not simply fall into the domain of one government ministry (or agency), instead it affects many of them. This creates a challenge of policy coordination.

Different governments have different ways of structuring ministries and agencies, but the main policy areas that are relevant in our context are education, employment, science \& technology, industry, economic development, and finance. One of the unique challenges of fostering university-based start-ups is that different ministries and agencies are likely to have different policy agendas. At this point it is useful to recall the funnel concept from Figures 1 and 2. While it is difficult to generalize, the overall pattern seems to be that ministries of education, employment, and science $\&$ technology tend to focus on the top of the funnel. These ministries place greater emphasis on universities developing students' entrepreneurial mind set and skillsets. By contrast, ministries of industry and finance tend to be more concerned with the bottom of the funnel. They are mainly interested in the rate at which new companies get created and funded. Each of these ministries is likely to affect a different part of the ecosystem, none have a holistic view or mandate.

Coordination of policies across different ministries is always challenging. Moreover, their objectives are unlikely to be perfectly aligned. This takes us back to some of the common challenges that we discussed in Section 4.4. Just like people within a university, different ministries within government may disagree on the relative importance of developing mind sets versus ventures. A way of addressing this challenge is to set up a government supported independent body whose mission is to address the challenges of the whole ecosystem. A strong and independent board of governors composed of leaders from the universities and the private sectors (large corporations, start-ups, and investors) is an important step to support the independence, professionalism, performance, and continuity of the organization. An example of this is the Ontario Centres of Excellence. Its mandate is "to drive the growth of a globally competitive, knowledge-based economy in Ontario". ${ }^{37}$

There is also a question of what levels of government should be involved. Some of our policy discussion applies to national governments, yet others pertain to regional or local

${ }^{37}$ See http://www.oce-ontario.org/about-us/our-mandate. 
governments. For example, interventions about creating entrepreneurship spaces involve real estate planning, and therefore tend to fall under the purview of local governments. In a few cases, there may also be a role for multinational governmental institutions. The European Investment Fund, for example, has a mandate of providing funding to venture capital firms across all its member states.

\section{Conclusion}

In this paper we examine the emergence of a second wave of entrepreneurial activities in and around universities. The first wave focussed on academic spin-offs, which emerged from the research side of universities. The second wave focuses on university-based startups and the role of the university in the entrepreneurship ecosystem. The later wave has been led mostly by students and alumni, and comes from across the entire range of degrees and programs.

We first provide a simple framework for understanding the structures within which these university-based start-ups emerge. We emphasize that in addition to the programmes and support structures within the university, university-based start-ups rely on an ecosystem around the university that includes mentors (broadly defined), corporations, and investors. Our paper identifies some of the promising new initiatives, but also examines some of the systemic challenges frequently encountered in these ecosystems.

The ultimate objective of this paper is to explore the role of government and public policy. For this we note that supporting an entrepreneurial ecosystem cannot be achieved with a single policy, but instead requires a combination policies, as well as some coordination across different parts of the government. Our analysis distinguishes two main types of policies: (i) policies that affect the internal actors, i.e., students, faculty, and university administrations, and (ii) policies that affect external parties who want to interact with the student entrepreneurs, especially investors and corporations. Our analysis identifies the main types of policy interventions, and discusses their potential benefits and costs.

This paper provides an exploratory analysis into the new wave of student-led entrepreneurship that is catching an increasing number of universities around the globe. Much research remains to be done. To begin with, there is a severe lack of systematic data about these trends. There is also a lack of data about the types of government interventions used to promote university-based start-ups. In addition to lack of data, important policy questions remain to be explored. While our analysis identifies several reasons as to why university-based start-ups might be encouraged, there are also arguments why such activities could become distractions. Exploring the appropriate balance between these competing forces remains a subject worthy of further research. 


\section{References}

Aghion Philippe, and Peter Howitt, 1992, "A Model of Growth through Creative Destruction" Econometrica 60(2): 323-351.

Aghion Philippe and Peter Howitt, 2009, The Economics of Growth, MIT Press.

Agrawal, A., C Catalini, and A. Goldfarb, 2014, "Some Simple Economics of Crowdfunding", IPE, University of Chicago Press, Vol. 14.1: 63-97, 2014.

Akerlof G. (1970), "The Market for Lemons: Quality Uncertainty and the Market Mechanism", Quarterly Journal of Economics 84, 485-500.

Arrow, K. 1962. "Economic welfare and the allocation of resources for inventions." In The Rate and Direction of Inventive Activity: Economic and Social Factors, ed. R. R. Nelson, pp. 609-626, Princeton: Princeton University Press

Audretsch, D., 2018, "Entrepreneurship, Economic Growth, and Geography" Oxford Review of Economic Policy, forthcoming.

Autio, E., 2010, "High-growth Entrepreneurship and its Determinants", Presentation at the OECD CIIE meeting, March 2010, Paris.

Becker, Gary, 1983, "A Theory of Competition Among Pressure Groups for Political Influence", Quarterly Journal of Economics, 63, pp. 371-400.

Blank, S. (2013) 'Why the Lean Start-Up Changes Everything,' Harvard Business Review, 91(5): 63-72.

Block, Joern, Christian O. Fisch, and Mirjam van Praag, 2018, "Quantity and Quality of Jobs by Entrepreneurial Firms: A Review", Oxford Review of Economic Policy, forthcoming.

Britos Cavagnaro, Leticia and Humera Fasihuddin, 2016, "A Moonshot Approach to Change in Higher Education: Creativity, Innovation, and the Redesign of Academia", 2016, Liberal Education, Spring, pp8-17

Brown, Tim, 2009, “Change by Design: How Design Thinking Transforms Organizations and Inspires Innovation", Harper Business, New York, New York, US

Chesbrough, H. (2003), 'The era of open innovation,' MIT Sloan Management Review, 44(3), 35-41

Cohen, Susan and Hochberg, Yael V., Accelerating Startups: The Seed Accelerator Phenomenon (March 30, 2014). Available at SSRN: https://ssrn.com/abstract $=2418000$ or http://dx.doi.org/10.2139/ssrn.2418000

Cohen, Wesley M., 2010, "Fifty Years of Empirical Studies of Innovative Activity and Performance," Chapter 4, Bronwyn Hall and Nathan Rosenberg, Handbook of Economics of Innovation, 129-213, Elsevier

Czarnitzki, D., Doherr T., Hussinger, K., Schliessler, P., Toole, A. (2017) “Individual versus institutional ownership of university-discovered inventions" 
Debackere, K. and R. Veugelers (2005), 'The role of academic technology transfer organizations in improving industry science links,' Research Policy, 34(3), 321-342

Duruflé, Gilles, 2016, Main Conclusions of the 2016 TIP Ecosystem Building Forum, available at https://qcconference.com/wp-content/themes/qcciir-v2.5/uploads/2016/2016-TIP-MainConclusions.pdf

Duruflé, Gilles, 2017, Main Conclusions of the 2017 TIP Ecosystem Building Forum, available at https://qcconference.com/wp-content/themes/qcciir-v2.5/uploads/2017/2017-TIP-EBFMain-Conclusions.pdf

European Forum for Entrepreneurship Research (EFER), 2007 “Universities as Centres of Dynamic Entrepreneurship.

Gerbin, A., Drnovsek, M. (2016) “Determinants and public policy implications of academic industry knowledge transfer in life sciences: a review and a conceptual framework", Journal of Technology Transfer (2016)

Graham, Ruth, 2014, "Creating university-based entrepreneurial ecosystems evidence from emerging world leaders" MIT SkolTech Initiative, June

Greenwald, Bruce C., Joseph E. Stiglitz, 1986, "Externalities in Economies with Imperfect Information and Incomplete Markets", The Quarterly Journal of Economics, Volume 101, Issue 2, 1 May 1986, Pages 229-264, https://doi.org/10.2307/1891114

Haltiwanger, John, Ron Jarmin, and Javier Miranda (2013) Who Creates Jobs? Small versus Large versus Young, Review of Economics and Statistics, Vol. 95, n. 2, pp.347-361.

Hellmann, Thomas and Veikko Thiele (2018), “Fostering Entrepreneurship: Promoting Founding or Funding?" forthcoming, Management Science

Holmström, Bengt, 1982, "Moral hazard in teams", The Bell Journal of Economics, 13(2), 324-340

Hvide, H., Jones, B. (2016), "University Innovation and the Professor's Privilege" Mimeo, Northwestern University

Kirzner, Israel M., 1973, “Competition and Entrepreneurship", University of Chicago Press, Chicago, IL, US.

Landier, A., 2006. Entrepreneurship and the Stigma of Failure. Unpublished working paper, University of Toulouse.

Lazear, Edward P. 2005, “Entrepreneurship,” Journal of Labor Economics 23, 4: 649-680.

Lerner, J., 2009, "Boulevard of Broken Dreams: Why Public Efforts to Boost

Entrepreneurship and Venture Capital Have Failed - and What to Do About It", Princeton University Press, Princeton, US

Lerner, J., 2012, "The architecture of Innovation", Harvard Business Review Press 
Lerner, Josh and Ulrike Malmendier, 2013, "With a Little Help from My (Random) Friends: Success and Failure in Post-Business School Entrepreneurship" The Review of Financial Studies, 26(10), pp. 2411-2452, https://doi.org/10.1093/rfs/hht024

Litan, Robert E., Lesa Mitchell, E.J. Reedy, 2007 “Commercializing University Innovations: A Better Way", NBER working paper.

Kerr, W., R. Nanda, and M. Rhodes-Kropf, 2014, "Entrepreneurship as experimentation" Journal of Economic Perspectives, 28 (3), 25-48.

Michelacci, C. and J. Suarez, 2004. Business Creation and the Stock Market. Review of Economic Studies 71, 459-481.

MIT, 2016, "Final report of community feedback and recommendations", MIT Innovation Initiative, January

Murphy, Kevin M., Andrei Shleifer and Robert W. Vishny, 1989, "Industrialization and the Big Push", Journal of Political Economy, Vol. 97, No. 5 (Oct., 1989), pp. 1003-1026

North, Douglass C., 1990, Institutions, Institutional Change, and Economic Performance, New York: Cambridge University Press.

O'Connor, Allan, 2013, “A conceptual framework for entrepreneurship education policy: Meeting government and economic purposes", Journal of Business Venturing, 28 (4), 546563.

OECD, 2008 'Entrepreneurship in Higher Education' OECD Publishing.

Olson, M., 1965, The Logic of Collective Action, Harvard University Press, Cambridge, MA, US Parker, Simon, 2018, "Entrepreneurship and Economic Theory" Oxford Review of Economic Policy, forthcoming.

Peltzman, Samuel, 1976, Toward a More General Theory of Regulation," Journal of Law and Economics" 19, pp. 211-40.

Richards, G., 2009, Spin-outs: Creating businesses from university intellectual property, HARRIMAN HOUSE, Petersfield, Hampshire, UK.

Ries, Eric, 2011, "The Lean Start-Up”, Crown Publishing Group

Roberts, Edward B., Fiona Murray, and J. Daniel Kim, 2015, "Entrepreneurship and Innovation at MIT Continuing Global Growth and Impact"

Romer, P. M. (1994). "The Origins of Endogenous Growth". The Journal of Economic Perspectives. 8 (1): 3-22. doi:10.1257/jep.8.1.3.

Sandström C., Wennberg K., Wallin M., Zherlygina Y., (2016) "Public policy for academic entrepreneurship initiatives: a review and critical discussion", Journal of Technology Transfer (2016) 
Schumpeter, Joseph (1934) "The Theory of Economic Development: An Inquiry into Profits, Capital, Credit, Interest, and the Business Cycle." New Brunswick, New Jersey: Transaction Books.

Schumpeter, Joseph A., (1942). Capitalism, Socialism and Democracy. London: Routledge. pp. $82-83$

Shane, Scott, 2004, "Academic Entrepreneurship: University Spinoffs and Wealth Creation" Edward Elgar, Cheltenham, UK.

Siegel, D.S., D.A. Waldman and A.N. Link (2003), 'Assessing the impact of organizational practices on the productivity of university technology transfer offices: an exploratory study,' Research Policy, 32(1), 27-48.

Siegel, Donald S., Reinhilde Veugelers, and Mike Wright, 2007, "Technology transfer offices and commercialization of university intellectual property: performance and policy implications", Oxford Review of Economic Policy, 23 (4) pp. 640-660.

Siegel, D. and Wright, M (2015), “Academic entrepreneurship: time for a rethink?” Entrepreneurship Research Centre, Research paper No. 32, June

Slemrod, J. 1990 "Optimal Taxation and Optimal Tax Systems", Journal of Economic Perspectives 4(1), 157-178

Wildavsky, Ben, 2010 'The Great Brain Race: How Global Universities Are Reshaping the World', Princeton University Press.

Wilson, K. (2011), Financing High-Growth Firms: The Role of Angel Investors, Paris: OECD Publishing.

Wilson, K. (2015), 'Policy Lessons from Financing Young Innovative Firms', OECD Science, Technology and Industry Policy Papers No. 9, OECD Publishing.

Wilson, K. and F. Silva (2013), 'Policies for Seed and Early Stage Finance', OECD Science, Technology and Industry Policy Papers No. 9, OECD Publishing.

Wright, Mike, Bart Clarysse, Philippe Mustar, and Andy Lockett, 2007, Academic Entrepreneurship in Europe, Edward Elgar, Cheltenham, UK. 